\title{
The Developmental Of Social Studies By Using Inquiry Model In Sdi Kardina Massa Blitar
}

\author{
Hadi Mustofa \\ Malang State University, Jl Semarang No 5 Malang Indonesia \\ E-mail: hadimustofapgsd3@gmail.com
}

Received: 21 April 2017; Revised: 2 May 2017; Accepted: 4 May 2017

\begin{abstract}
The observation results of Social studies process in Islamic Elementary School Blitar city are founded many problems. They are: (1) Social studies is not interesting, (2) the study is not meaningful for the students, (3) the students feel bored with the study, (4) the concepts which are presented to the students are separately, (5) the study is limited to read a book or hear an explanation, and (6) the result score of social studies is low. Based on those problems above, so it needs a study model exchange which more interesting than before. One of the study models which can be done is social study which has an inquiry. This research uses developmental model which is done by many steps: (1) introduction study, (2) developmental model, (3) test model. The results of this research are shown that Social studies by using inquiry study model is effective and efficient to increase the student competence for getting knowledge, attitude, and skills as the goals of the study. In particular, attitude and skills which are mastered by the student are scientific attitude and skills.
\end{abstract}

Key words: development; social studies; inquiry;

\section{Introduction}

Social studies is an integration of many social branches of studies, such as sociology, history, geography, economic, politic, law and culture (Trianto, 2007:171). As an integration of social studies branches, social studies are learned for an education. Social studies are one of the lessons which are given from SD/MI/ SDLP to SMP/MTs/SMPLB. IPS examines many events, facts, concepts, and generalization which are related to the social issues. For the $\mathrm{SD} / \mathrm{MI}$, social studies accommodates geography, history, sociology, and economy. By using social studies, the students are directed become Indonesian citizen who are democratic, and re- sponsible, and also love peace.

Social studies is planned to develop knowledge, comprehension, and analysis ability toward society social condition to enter the dynamic social life. Then, the self establishment of Indonesian which is heterogeneous in many aspects, such as religion, socio cultural language, ages, and ethnic group become Indonesian citizen which are intellegent, skilled person, and characterized according to Pancasila and UUD RI Year 1945. Nurmuliyati (2014:122) states that the goal of social studies is to introduce knowledge to the students about society life systematically.

Based on the observation result which is done toward the social studies process in SDI 
Kardina Massa Kota Blitar, it contains many problems, such as: (1) social studies which is conveyed by the teachers is not interesting because the study is centered by the teachers, (2) the students have less opportunity to develop their ideas and their mind until the study is not meaningful for the students, (3) the students feel bored with the lesson because the students only memorize the concepts which are conveyed in the lessons, (4) the concepts which are conveyed to the students are given separately, (5) the students cannot remember the lesson because the study is limited by reading a book or hearing an explanation, and (6) the the score result of IPS study is above Minimal Completeness Criteria (KKM).

Based on many problems above, so it needs a study which is done by an authentic context give an opportunity to the students to do the meaningful assignment, give the meaningful experience, it is done through study group, give priority of togetherness, and it is done by enjoyable. One of the study models which have those characteristics is social studies for SD with an inquiry.

Inquiry based on Sapriya (2009: 141) is a process for asking the meaning or other meaning which strive someone for showing their intellectual skills because its idea can be understand. Inquiry is one of study ways or research something which its characterization is to look for something critically, analytically, argumentatively (scientific) by using certain steps to get a conclusion (belief), which convinces someone because it is supported by data/facts/ arguments. Inquiry also indicates that knowledge is build through a meaningful activity.

Based on the explanation above, inquiry method contains meaning as one of study method which emphasized on the student activity, which is a maximal to look for or find, it means that students as the subject of study. This method which can be drive the students to realize what have had before during the study process. Inquiry studies is oriented to the student involvement which is maximal in study process activity, develop their self belief about what it is founded in an inquiry process.

A study by using inquiry method consists of many steps/scientific activity. American phi- losopher of education well known, John Dewey (in Sapriya, 2009:81) states that study process by using inquiry method consists of five steps, are: (1) drawing problem indicators, (2) giving possibility answer, (3) collecting facts which can be used to examine the data correctness, (4) examines the data correctness, (5) formulating conclusion which is supported by the best facts. Then, there are many inquiry method steps which is stated by Majid (2014:224) are (1) orientation, (2) formulating problem, (3) formulating hypothesis, (4) collecting data, (5) examines hyphotesis, and (6) formulating conclusion.

From those five steps, inquiry can give many benefits, such as (1) develop the students' skills to solve their problem and take their decision objectively and independently, (2) develop their ability to think (3) through inquiry, their ability to think is processed in condition which is understand, it is interested by the student in many alternative, (4) develop the student's curious (want to know more) and the way of thinking objective-independently, critical-analytical, individually or group.

Seeing the problems which happen and also solution which are offered, then this research is needed and important to be done. Then, this research is planned to achieve the goals, such as (1) identify study model which are used SD teacher to achieve competency in social studies which is hoped and (2) make equipment of social studies for elementary school by using inquiry model.

\section{Material and Method}

This research is development research. It is focused on a product include strategy for increasing the study qualiy. That is in relation to Ibnu (2013:3). This development research does not to examine theory, but to develop and examine an effective strategy. Then, Akbar (2016:2) states that this research is to validity and also give products/tools/equipment/ to an education and study. Furthermore, this developmental research produces a product as a creation function to increase the study quality.

To develop the equipment study model of social studies based on inquiry in SDI Kardina Massa Blitar, in this research is used study research development from Borg dan Gall (modification from Sukmadinata). As a big line, 
the research steps and development consists of three steps, (1) introduction study, (2) development model, (3) test model. Furthermore, this research is also designed by determine the data and the source of data; data analysis technique; instrument and data analysis technique; and validity data.

The research location is in SDI Kardina Massa by subject is students of fifth grade which are consists of thirthy five students, and also teacher model. It is hoped that all of participant give an evaluation and a reflection to the teacher model or researcher. The teacher who becomes a model in this research is the teacher of the fourth grades in the school where data are taken. Data which are collected, include implementation data process in social studies apply cooperative script and the result of study video validity.

The data process is achieved through: (1) questionnaire, (2) interview toward the student readiness, (3) observation toward I social studies implementation study apply cooperative script strategy based on cooperative character and appreciate opinion. While, the result data is achieved through validity expert study toward study video which is resulted.

Based on the step which is developed by Berg and Gall (Modification from Sukmadinata, 2015), the researcher doing this development research into three commonly steps, such as (1) introduction study, (2) test product, (3) the power product. In this first step, introduction study is the beginning or preparation to develop. This step consists of three steps: (1) library study, (2) field survey, (3) beginning product arrangement.

The second step is a trial test of development product on study model. In this step, there are two steps. First step is to do limited trial test and the second step is widder than before. The third step of prouct test is the power test from product which is produced. In this research is to examine the power model of inquiry study for social studies, if it is comparing with the study in the school.

The data analysis in this research follows the analysis data steps; include (1) data reduction, (2) data presentation, and (3) drawing explanation. Data reduction is a process to select or choose the data which is collected, focused and simplified data until the presentation data. Data presentation is done to organized the result of reduction by arrange all of the information which taken from the result of reduction until possibility to get a conclusion from the product. The conclusion is taken from the core of data from the result of the the research which is reduced and presented. The conclusion will show the success from the research development.

\section{Results and Discussion Result}

This research is starting by doing research toward social studies for the fifth grade in Elementary School. It is used to find which lesson is relevant with an inquiry model application. Therefore, it is founded that social studies is to recognize the change of intermediate level which happen in the society life and also Indonesian citizenship in colonial era, nationalism era, and the change in social, economic, education and cultural aspects. That lesson is used in this research.

Then, the observation is done in SDI Kardina Massa. That observation is done to look for which classes will be a subject and an object in this research. This research is done by teacher interview whose becomes a teacher model. Then, it is also done by the same perception about the object in this research. The same perception is important because subject and researcher have the same perception in relation to this research

The first research is in relation to collected data through questionnaire. It shows that (1) teacher model feels difficulties to arrage lesson plan by using inquiry model on social studies, (2) teacher model discusses with the research in arrange the implementation study planning, (3) teacher model is doing a lesson plan revision which is arraged based on the result discussion with the researcher, (4) teacher model is ready to do implementation inquiry model in social studies.

Then, this research is done by the implementation social studies by using inquiry model. In this implementation, the studying and teaching activity is documented into video studies. Then, that video becomes the first product from the result of the research. That video is given to the validator to examine the propeness. In this activity, it will be examine the teacher and students' 
activity during the studying and teaching activities.

The observation is done and it is also shown that (1) the teacher model cannot feel free to teach social studies which is using inquiry model, (2) the steps of inquiry study model does not apply altogether, (3) from six steps about inquiry model study, the step to formulate the problem and examine hypothesis, the teacher has not to do that, (4) the time which is applied is not appropriate with the time which is planned, (5) students activity does not show the inquiry work steps and it has not show a scientific attitude.

Based on data is done an analysis to achieve the goal of research. The result shows that data which are taken has not show the achievement of the result study. So, it will be taken a decision to apply again by using many revisions. The revision is to examine the characteristics and inquiry implementation model of social studies in Elementary School, understand the character student of elementary school, planning again the lesson plan based on the result discussion with researcher.

After the research is done effectively, it is done again an implementation social studies by using inquiry study model. In that implementation is documented become a video. The research location, subject and object are similar with the implementation before. It is also similar with the observation toward teacher activity and student activity during studying and teaching process.

The second implementation shows many revisions which is significant in study and teaching process; (1) In his implementation, teacher can get self belief, so that he/she can apply the inquiry study model effectively; (2) teacher model can apply six steps of inquiry study model by good; (3) the six steps of inquiry implementation is used in the study process; (4) the time which is used by the teacher is appropriate with the time planning; (5) Student activity shows revision by revealing scientific attitude which are honest, critical thinking and want to know; (6) the study is on going systematically; (7) the goals of study is achieved, such as listed in study planning program..

Study video in the second implementation is given to the expert to show the study video. It is facted by recommendation such as (1) study video has show iquiry implementation model in social studies; (2) the teacher model has done the social studies by using inquiry model based on syntac; (3) in this video, the students show the attitude based on inquiry model; (4) the conclusion, the video can be used by using inquiry model for teaching social studies.

\section{Discussion}

The result study shows that teacher feel diffult to apply social studies by using inquiry model in terms of planning. That result shows that teacher model is mastering about inquiry model application, especially in social studies. Therefore, the teacher model does not have self belief to apply inquiry model. The effects on the first implementation, the video does not require the standard planning. The steps of inquiry model do not apply all of them. From the six inquiry model, there are only three steps which are applied. The student activity does not show the activity such as the steps in inquiry model. So, the goal of the study is not achieve.

In the second implementation and planning more be prepared. The effect gives the activity based on the planning. In the second implementation, teacher can apply inquiry six models. Teacher teachs based on inquiry model steps. Jhon Dewey (dalam Sapriya, 2009: 81) states that inquiry model study follows five steps (1) drawing problem indicators; (2) give an possibility answer; (3) collect the facts which is used; (4) test the truthworties based on the colleted data; (5) formulate the conclusion which supported by the best facts. The step by using inquiry method based on Majid (2014:224) are (1) orientation, (2) formulate the problem, (3) formulate the hypotesis, (4) collect data, (5) examine hypotesis, and (6) formulate the conclusion.

Beside the implication of inquiry model study, the study goal is also achieved similar to what have been planned. On the other side, it is found that the scientific attitude in the student activity during the teaching and studying processess. An attitude which is founded is critically thinking, honest, and is want to know. This is in accordance with Harlen (in Widiadnyana, 2014) which states that students' scientific attitudes are categorized into four aspects: curiosity, respect 
for facts or evidences, ability to change views, and critical thinking. These attitudes are includes a scientific attitude that needs to be applied early.

The emergence of this attitude is one of the advantages of implementing inquiry model in learning. This is supported by Majid (2014: 222) who states that the purpose of using inquiry strategy is to develop systematic, logical, and critical thinking skills, or develop intellectual ability as part of mental processes. Roestiyah (In Saliman, 2010: 8) states that inquiry is an extension of the discovery process which is used in more mature ways. In addition to the discovery process, inquiry contains higher level mental processes, such as formulating problems, designing experiments, conducting experiments, collecting and analyzing data, drawing conclusions, fostering objective, honest, curiosity, openness and so on.

Referring to both opinions, it is known that the inquiry method not only teaches students to think critically and find problem solving, but also form an objective, honest attitude and high curiosity. These attitudes are mandatory attitudes that must be possessed by scientists. It can be said that the method of inquiry can develop the attitude of scientists in the students themselves.

Based on this, it can be seen that in the application of this learning model is not only achieve the learning objectives of the knowledge aspect, but it also achieves learning objectives from the aspects of the sail. It is proved by the observed attitudes that arise in the students' behavior during the learning activities. It can be said that the results of this study indicate the achievement of learning objectives in accordance with what is expected in aspects of knowledge and attitude.

The learning outcomes of these two aspects are part of the assessment of three aspects. The third aspect is skill. Implicitly, in the implementation, the students have been skilled in collecting data and drawing a conclusion from the data obtained. The learning outcomes of these three aspects support the diversity of students' abilities. It is because not all of students are expert. Sometimes, there are students who are skilled in attitude or skill. Assessment of these three aspects is supported by Kingsley (in Sudjana, 2009: 22) who divides learning outcomes into three kinds, namely (1) skills and habits, (2) knowledge and direction, (3) attitudes and ideals.

The emergence of these attitudes in addition to the impact of the application of scientific steps is also one of the expected learning results in the implementation of the curriculum 2013. It is because in the Curriculum 2013, character education becomes one part in the component curriculum. Character education is an attempt to shape the attitude and mental students Carcinoma. Character Education is the process of giving participants / student guidance in order to become a whole person who characterized in the dimensions of heart, mind, body, and taste and karsa (Revelation, 2011: 142). Character education is an effort to cultivate the values of character to the school community which includes the components of knowledge, awareness, or willingness, and actions to carry out those values, both to God Almighty, self, fellow, environment (Samani, 2013: 46).

Bier and Berkowitz (in Supraptiningrum, 2015: 221) argue that character education is the creation of a school environment that helps students in ethical development, responsibility through modeling and teaching of good character through universal values. Further, Zainuddin (2012: 23) defines character education as a genuine effort to understand, shape, nurture ethical values, both for oneself and for all citizens or citizens as a whole. Therefore, in every teaching and learning activity, teachers must implement the value of nation's cultural character.

In the development of character education, there are many characters that must be implemented in teaching and learning activities. The characters are (1) Religious, (2) Honest, (3) Tolerance, (4) Discipline, (5) Hard Work, (6) Creative, (7) Self, (8) Democratic, (9) Love of the Homeland, (10) Respect for Achievement, (11) Friendly or Communicative, (12) Daunting Love, (13) Reading, (14) Caring for the Environment, (15) Social Care, (16) Responsibility (in Princess, 2011: 9). In those characters, the character of cooperation and appreciate the opinions are described with the character of social and democratic care.

In terms of learning objectives, in this study shows that the learning objectives of social stud- 
ies designed by the model teacher has been achieved. From the aspect of subject objectives has been achieved is shown by the emergence of social attitudes of students in the form of character of cooperation and appreciate the opinion. From the designed objectives is not just measuring knowledge, but also attitudes in particular familiarizing students to cooperate and appreciate opinions. It shows that the goals in this study have been referring to the function and purpose of national education.

National education function to develop the ability and form the character and civilization of dignified nation in order to educate the life of the nation, aiming for the development of potential learners to become human beings who believe and fear God Almighty, have noble character, healthy, knowledgeable, capable, creative, independent, and become a democratic and responsible citizen (Law No. 20 of 2003). The above is in accordance with the mandate of the Basic Laws 1945 of Article 31 Paragraph 3 that the Government undertakes and organizes a national education system, which enhances faith and piety and noble morals in order to educate the life of the nation, which is regulated by law.

Thus, the results obtained that learning social studies by using inquiry model is effectively and efficiently in improving student competence in terms of knowledge, attitudes and skills of students as part of the achievement of learning objectives. In particular, the attitudes and skills that students master are scientific attitudes and skills.

\section{Conclusion}

Based on the result of the research and explanation, so it can be concluded that (1) teacher model can apply the inquiry model in social studies; (2) the students and the teacher can do the study process better than before; (3) the inquiry development model in social studies is effectively and efficiently to achieve the goals of study and reveals the scientific attitude for the elementary student.

\section{Suggestion}

In develop the inquiry model study in social studies must be understand the implementation from that model. The teacher is hoped un- derstand the characteristics of social studies by using inquiry model. The most important thing is in planning model, the teacher must be ready to teach.

\section{Reference}

Akbar, Sa'dun. 2016. Riset Pengembangan untuk Pengembangan Alat Pembelajaran. Makalah disajikan dalam Lokakarya Penyusunan Proposal Penelitian Didanai DRPM DIKTI, FIP UM, Malang, 2 Mei 2016.

Ibnu, Suhadi. 2013. Penelitian Pengembangan. Malang: UM Press.

Majid, Abdul. 2014. Strategi Pembelajaran. Bandung: Remaja Rosdakarya.

Nurmuliyati, Sisti.,\& Sirajuddin. 2014. Penerapan Model Pembelajaran Inkuiri untuk Meningkatkan Hasil Belajar IPS dengan Materi Konsep Peta pada Siswa Kelas IV Sekolah Dasar. Jurnal Pendidikan Guru Sekolah Dasar, 2 (3): 121-130.

Putri, Noviani Achmad. 2011. Penanaman Nilainilai Pendidikan Karakter melalui Mata pelajaran Sosiologi.Komunitas, (Online), 3 (2): 201-215, (http://journal.unnes.ac.id/nju/ in dex.php/ k o m unitas/article/ download/2317/2370), diakses tanggal 23 Juli 2016.

Saliman 2010.Pendekatan Inkuiri dalam Pembelajaran.(Online) (http://staff.uny.ac.id/ sites/default/files/penelitian/Saliman, $\%$ 20 Drs. \%20M.Pd./PENDEKATAN\% 20INKUIRI.pdf), diakses 2 Desember 2014.

Samani, Muchlas.,\& Hariyanto. 2013. Konsep \& Model Pendidikan Karakter. Bandung: PT Remaja Rosda Karya.

Sapriya. 2014. Pendidikan IPS. Bandung: Remaja Rosdakarya.

Sudjana, Nana. 2009. Penilaian Hasil Proses Belajar Mengajar.Bandung: PT Remaja Rosda Karya.

Sukmadinata, Nana Sayodih. 2015. Metode Penelitian Pendidikan. Bandung: Remaja Rosdakarya.

Supraptiningrum \& Agustini.2015. Membangun Karakter Siswa Melalui Budaya Sekolah di Sekolah Dasar.Jurnal Pendidikan Karakter, (Online), 5 (2): 219-228, (http:// journal.uny.ac.id/index.php/jpka/article/ 
viewFile/8625/7118), diakses tanggal 23 Juli 2016.

Trianto. 2007. Model-Model Pembelajaran Inovatif Berorientasi Konstruktivistik. Jakarta: Prestasi Pustaka.

Undang-undang Dasar 1945 dan amandemennya.2013. Sekretariat Jenderal Majelis Permusyawaratan Republik Indonesia.

Undang-undang RI No. 20 tahun 2003 tentang Sistem Pendidikan Nasional.Sekertariat Negera Republik Indonesia.(Online), (www.setneg.go.id), diakses 11 Juli 2016.

Wahyu. 2011. Masalah dan Usaha Membangun Karakter Bangsa. Komunitas, (Online), 3 (2): 138-149, (http://journal.unnes.ac.id/ $\mathrm{n} \mathrm{j} \mathrm{u} \mathrm{/} \mathrm{i} \mathrm{n} \mathrm{d} \mathrm{ex} \mathrm{.} \mathrm{p} \mathrm{h} \mathrm{p} \mathrm{/} \mathrm{k} \mathrm{o} \mathrm{m} \mathrm{u} \mathrm{n} \mathrm{i} \mathrm{a} \mathrm{s} \mathrm{/}$ article/2310/2363), diakses tanggal $23 \mathrm{Juli}$ 2016.

Widiadnyana, IW., Sadia, IW, \& Suastra, IW. 2014. Pengaruh Model Discovery Learning Terhadap Pemahaman Konsep IPA dan Sikap Ilmiah Siswa SMP. E-journal Program Pascasarjana Universitas Pendidikan Ganesha, 4 (2): 71-83. diakses tanggal 12 Agustus 2016.

Zainuddin. 2012. Membentuk Karakter Anak Bangsa. Malang: Universitas Negeri Malang. 